\title{
Decyzje terapeutyczne w nadciśnieniu tętniczym - czy inhibitory konwertazy angiotensyny powinny być preferowane?
}

\author{
prof. dr hab. n. med. Danuta Czarnecka \\ I Klinika Kardiologii i Nadciśnienia Tętniczego, Collegium Medicum, Uniwersytet Jagielloński, Kraków
}

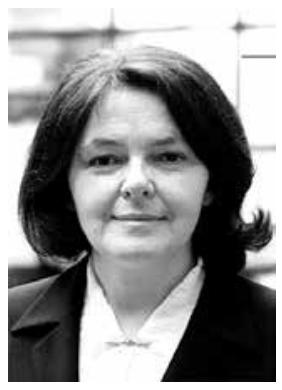

Układ renina-angiotensyna-aldosteron (RAAS, renin-angiotensin-aldosterone system) stanowi nieodzowny element regulacji ciśnienia tętniczego oraz funkcji układu krążenia i nerek. Leki hamujące RAAS, zwłaszcza inhibitory konwertazy angiotensyny (ACEI, angiotensin-converting enzyme inhibitors) oraz antagoniści receptora angiotensyny II (ARB, angiotensin II receptor blockers), reprezentują główne klasy leków stosowanych w nowoczesnym leczeniu nadciśnienia tętniczego.

Miejsce ACEI oraz ARB w postępowaniu przeciwnadciśnieniowym wynika z ich skuteczności hipotensyjnej, wysokiej tolerancji oraz udowodnionego działania odwracającego uszkodzenia narządów docelowych i zapobiegania ich powstaniu. Kontrolowane badania kliniczne wykazały, że leki obu tych klas zmniejszają chorobowość sercowo-naczyniową i śmiertelność z powodu chorób układu krążenia. W „Kardiologii Polskiej” ukazał się interesujący artykuł Prof. Roberto Ferrariego [1], w którym dokonano przeglądu różnic farmakologii tych dwóch klas leków i dostępnych danych wskazujących na wynikające z nich dowody skuteczności klinicznej obu klas leków.

Inhibitory ACE, poza blokowaniem konwersji angiotensyny I do angiotensyny II, hamują również degradację bradykininy. Ten mechanizm działania, choć niedoceniany klinicznie, powoduje m.in. zwiększenie biodostępności tlenku azotu i innych czynników naczyniorozszerzających, prowadząc do ochrony śródbłonka naczyniowego. Z kolei ARB działają biologicznie poprzez selektywną blokadę receptorów angiotensyny II typu 1 (AT1), pozostawiając możliwość stymulacji przez angiotensynę II innych jej receptorów, co może prowadzić do niezamierzonych efektów klinicznych. Na przykład, choć postulowano, że stymulacja receptorów AT2 prowadzi do wazodylatacji, nowsze dane sugerują, że receptor ten może być również zaangażowany w promowanie niekorzystnego remodelingu naczyń, zapalenia i włóknienia [2].

Mając na uwadze możliwe różnice efektów klinicznych, wynikające z odmiennych mechanizmów blokady RAAS przez obie grupy leków, Prof. Ferrari przywołuje wyniki metaanalizy opublikowanej w „European Heart Journal” w 2012 roku, dotyczącej porównania wpływu ACEI oraz ARB na śmiertelność pacjentów z nadciśnieniem tętniczym [3]. Analiza objęła 20 badań klinicznych oceniających chorobowość i śmiertelność sercowo-naczyniową. Do opracowania włączano badania, w których u co najmniej dwóch trzecich pacjentów rozpoznano nadciśnienie tętniczego oraz w których pacjenci byli losowo przydzielani do grupy aktywnego leczenia inhibitorem RAS lub do grupy otrzymującej placebo.

Badana kohorta objęła 158998 osób (71 401 otrzymywało inhibitor RAAS; 87597 przyjmowało placebo). Śmiertelność całkowita wyniosła 20,9 i 23,3 na 1000 pacjentolat, odpowiednio u pacjentów randomizowanych do inhibitora RAAS oraz do grupy kontrolnej.

Hamowanie RAAS wiązało się z 5-procentową redukcją śmiertelności ogólnej (HR: 0,95, 95\% Cl: 0,91-1,00, $\mathrm{p}=0,032)$ oraz 7-procentowym zmniejszeniem śmiertelności sercowo-naczyniowej (HR: 0,93, 95\% Cl: 0,88-0,99, $p=0,018)$. Obserwowany efekt leczenia wynikał wyłącznie ze stosowania klasy ACEI, które wiązało się z istotnym 10-procentowym obniżeniem śmiertelności całkowitej (HR: 0,90, 95\% Cl: 0,84-0,97, $\mathrm{p}=0,004)$, natomiast w grupie leczonej ARB nie wykazano zmniejszenia śmiertelności (HR: 0,99, 95\% Cl: 0,94-1,04, p = 0,683). Różnica efektu terapeutycznego między ACEI a ARB w odniesieniu do śmiertelności całkowitej była istotna statystycznie ( $p$ dla heterogeniczności $=0,036$ ).

Opracowanie van Vark i wsp. [3] jest pierwszą dotychczas opublikowaną metaanalizą, która ocenia wpływ inhibitorów RAAS na śmiertelność w ich podstawowym wskazaniu, jakim jest nadciśnienie tętnicze. Jej wyniki potwierdzają i rozszerzają wcześniejsze doniesienia wskazujące na zmniejszenie chorobowości i śmiertelności pod wpływem leczenia ACEI, natomiast nie pod wpływem ARB.

Strauss i wsp. [4] przeprowadzili metaanalizę 11 badań klinicznych (55 050 pacjentów) porównujących ARB z placebo lub leczeniem aktywnym i wykazali, że stosowanie ARB prowadziło jedynie do zmniejszenia ryzyka udaru mózgu [4]. Nie stwierdzono zmniejszenia śmiertelności całkowitej, natomiast ryzyko zawału serca było istotnie - o 8\% — zwiększone u pacjentów otrzymujących ARB (95\% Cl: 1-16\%, p = 0,03). 
Identyczna analiza przeprowadzona dla ACEI wskazała na zmniejszenie śmiertelności ogólnej, śmiertelności sercowo-naczyniowej oraz ryzyka zawału serca, odpowiednio o 9, 12 i 14\% (różnice istotne statystycznie) [4].

Do kolejnej metaanalizy opublikowanej w 2011 r. [5] włączono wszystkie randomizowane badania kliniczne porównujące ARB z placebo lub aktywnym leczeniem, w sumie 37 badań obejmujących ponad 147000 pacjentów. W porównaniu z grupą kontrolną ARB nie okazały się być związane ze zmniejszeniem ryzyka zawału serca [ryzyko względne (RR): 0,99, 95\% Cl: 0,92-1,07]. Nie stwierdzono również zmniejszenia ryzyka zawału serca w badaniach klinicznych porównujących ARB z placebo (RR: 0,93, 95\% Cl: 0,81-1,07), ani też zmniejszenia śmiertelności ogólnej czy sercowo-naczyniowej, chociaż u badanych leczonych ARB wartości ciśnienia tętniczego były mniejsze niż w grupie otrzymującej placebo. W porównaniu z leczeniem aktywnym względne ryzyko zawału serca u pacjentów randomizowanych do ARB wynosiło 1,04 (95\% Cl: 0,98-1,11), podczas gdy ryzyko zgonu z jakiejkolwiek przyczyny i zgonu sercowo-naczyniowego nie zmniejszyły się [5].

Wyniki metaanalizy van Vark i wsp. [3] są również spójne z ostatnio opublikowaną metaanalizą 26 randomizowanych badań klinicznych [6], oceniającą efekty kliniczne stosowania ARB lub ACEI w porównaniu z placebo u 108212 pacjentów wysokiego ryzyka sercowo-naczyniowego, bez niewydolności serca w odniesieniu do złożonego punktu końcowego (zdefiniowanego jako zgon z przyczyn sercowo-naczyniowych, zawał serca lub udar mózgu), śmiertelności ogólnej, nowych rozpoznań niewydolności serca oraz nowych rozpoznań cukrzycy. Stwierdzono, że zarówno ACEI, jak i ARB zmniejszają ryzyko złożonego punktu końcowego, natomiast jedynie ACEI wykazywały wpływ na redukcję śmiertelności całkowitej [iloraz szans OR: 0,908 (95\% Cl: 0,845-0,975); $\mathrm{p}=0,008]$, nowych rozpoznań niewydolności serca [OR: 0,789 (95\% Cl: 0,686-0,908); $p=0,001]$ oraz nowych rozpoznań cukrzycy [OR: 0,851 (95\% Cl: 0,749-0,965); $p=0,012][6]$.

Prof. Ferrari w swoim artykule podkreśla, że korzystne dla ACEI wyniki metaanalizy van Verk i wsp. [3] wynikają głównie z badań klinicznych, w których stosowanym ACEI był perindopril. Rozpatrując pojedyncze badania ujęte w metaanalizie, należy zwrócić uwagę, że istotną redukcję śmiertelności ogólnej stwierdzono w 3 z 7 badań klinicznych z ACEI: ASCOT-BPLA (Anglo-Scandinavian Cardiac Outcomes Trial Blood Pressure Lowering Arm), ADVANCE (Action in Diabetes and Vascular disease: PreterAx and DiamicroN MR Controlled Evaluation) oraz HYVET (HYpertension in the Very Elderly Trial), względne ryzyko zgonu z jakiejkolwiek przyczyny było zmniejszone odpowiednio o $11 \%(p=0,025), 14 \%(p=0,025)$ oraz $21 \%(p=0,02)$. Ramiona aktywnego leczenia wszystkich tych badań klinicznych zawierały perindopril.
Po publikacji opracowania van Vark i wsp. pojawiły się do niej pewne zastrzeżenia, dotyczące zakresu włączonego materiału oraz stosowania leczenia skojarzonego w badaniach objętych metaanalizą. Pierwszorzędowym, określonym a priori przez autorów celem metaanalizy było sprawdzenie hipotezy, według której inhibitory RAAS jako cała klasa terapeutyczna mogą korzystnie wpływać na zmniejszenie śmiertelności całkowitej u pacjentów z nadciśnieniem tętniczym w porównaniu ze współczesną hipotensyjną terapią kontrolną. Dlatego zapewne zdecydowano o włączeniu badań opublikowanych po 2000 r., kiedy to już leczenie skojarzone nadciśnienia tętniczego jest uznaną metodą postępowania terapeutycznego, a nawet rozpoczynania terapii hipotensyjnej. Obserwowana w metaanalizie redukcja śmiertelności ogólnej praktycznie w całości zależała od działania ACEI, natomiast korzyść leczenia ARB nie była wyraźna. Ten efekt terapeutyczny został osiągnięty u pacjentów otrzymujących inne leki obniżające ryzyko sercowo-naczyniowe, łącznie ze statynami, leczeniem przeciwpłytkowym, $\beta$-adrenolitykami, diuretykami oraz innym lekami hipotensyjnymi. Wydaje się więc, że złożona terapia przeciwnadciśnieniowa oparta na ACEI powinna stanowić podstawę postępowania u pacjenta z nadciśnieniem tętniczym.

W wytycznych European Society of Cardiology-European Society of Hypertension (ESC/ESH) postępowania w nadciśnieniu tętniczym pochodzących z 2007 r. stwierdza się, że wszystkie klasy leków hipotensyjnych mogą być rozpatrywane jako leki pierwszego rzutu [7]. Te same wytyczne wymieniają jednak szereg szczególnych sytuacji klinicznych będących wskazaniem do zastosowania ACEI. W odniesieniu do ARB szczególne wskazania do podawania tej klasy leków są tożsame ze wskazaniami do zastosowania ACEI, z jednym wyjątkiem, jakim jest stwierdzenie u pacjenta kaszlu spowodowanego ACEI [7].

Dotychczas jedynie w 2 dużych badaniach klinicznych porównano bezpośrednio ACEI z ARB: ONTARGET (pacjenci wysokiego ryzyka) oraz DETAIL (pacjenci z nefropatią cukrzycową). Nie wykazano w nich różnic pomiędzy tymi klasami leków, choć w obu badaniach telmisartan prowadził do większej redukcji ciśnienia tętniczego niż ramipril w badaniu ONTARGET oraz niż enalapril w badaniu DETAIL $[8,9]$.

Podsumowując, ponieważ celem postępowania w nadciśnieniu tętniczym jest zmniejszenie zachorowalności i śmiertelności sercowo-naczyniowej oraz śmiertelności całkowitej, szczególną uwagę należy zwrócić na wybór leczenia u pacjentów z nadciśnieniem tętniczym wysokiego ryzyka sercowo-naczyniowego. Wyniki ostatnich badań klinicznych i metaanaliz wskazują, że leczenie ACEI, natomiast nie ARB, prowadzi do statystycznie istotnej dalszej redukcji śmiertelności u pacjentów z nadciśnieniem. Inhibitory ACE powinny być uważane za leki pierwszego wyboru u pacjentów ze wskazaniami do leczenia inhibitorem RAAS.

Konflikt interesów: nie zgłoszono 


\section{Piśmiennictwo}

1. Ferrari R. RAAS inhibition and mortality in hypertension: from pharmacology to clinical evidence. Kardiol Pol, 2013; 71: 1-7.

2. Levy BI. Can angiotensin II type 2 receptors have deleterious effects in cardiovascular disease? Implications for therapeutic blockade of the renin-angiotensin system. Circulation, 2004; 109: 8-13.

3. van Vark LC, Bertrand M, Akkerhuis KM, Brugts JJ, Fox K, Mourad J-J, Boersma E. Angiotensin-converting enzyme inhibitors reduce mortality in hypertension: a meta-analysis of randomized clinical trials of renin-angiotensin-aldosterone system inhibitors involving 158998 patients. Eur Heart J, 2012; 33: 2088-2097.

4. Strauss MH, Hall AS. Angiotensin receptor blockers may increase risk of myocardial infarction: unraveling the ARB-MI paradox. Circulation, 2006; 114: 838-854.

5. Bangalore S, Kumar S, Wetterslev J, Messerli FH. Angiotensin receptor blockers and risk of myocardial infarction: meta-analyses and trial sequential analyses of 147020 patients from randomised trials. BMJ, 2011; 342: d2234.

6. Savarese G, Costanzo P, Cleland JG, Vassallo E, Ruggiero D, Rosano G, Perrone-Filardi P. A meta-analysis reporting effects of angiotensin-converting enzyme inhibitors and angiotensin receptor blockers in patients without heart failure. J Am Coll Cardiol, 2013; 61: 131-142. Epub 2012 Dec 5.

7. Mancia G, De Backer G, Dominiczak A et al; ESH-ESC Task Force on the Management of Arterial Hypertension. 2007 ESH-ESC Practice Guidelines for the Management of Arterial Hypertension: ESH-ESC Task Force on the Management of Arterial Hypertension. Eur Heart J, 2007; 28: 1462-1536.

8. ONTARGET Investigators. Telmisartan, ramipril, or both in patients at high risk for vascular events. NEngl J Med, 2008; 358: 1547-1559.

9. Barnett AH, Bain SC, Bouter P et al; Diabetics Exposed to Telmisartan and Enalapril Study Group. Angiotensin-receptor blockade versus converting-enzyme inhibition in type 2 diabetes and nephropathy. N Engl J Med, 2004; 351: 1952-1961. 